\title{
PENYELESAIAN TINDAK PIDANA RINGAN DILUAR PERADILAN SEBAGAI UPAYA PENCAPAIAN RASA KEADILAN
}

\author{
Yoyok Ucuk Suyono \\ Fakultas Hukum Universitas Dr Soetomo Surabaya Jawa Timur, Indonesia \\ Email : yoyokucuk123@gmail.com
}

\begin{abstract}
ABSTRAK
PenyidikKepolisian dalam penyelesaian perkara tindak pidanaringan dalamhalinipencurian ringan, biasanya dengan mediasi penal yang petimbangannya karena supaya tercapainya keadilan hukum, kepastian hukum,dan kemanfaatan dengan tetap mengedepankan asas peradilan yang sederhana, jadi kerugian korban dapat segera di kembalikan, agar efisiensi waktu yang dapat di selesaikan lebih cepat, kemudian dari segi biaya penanganan perkara lebih ringan atau lebih sedikit dibandingkan dengan kasus yang di proses lanjut sampai persidangan. Namun hal tersebut tidak menjadikan solusi terbaik untuk pelaku tindak pidana ringan dalam hal ini pencurian ringan, karena pelaku dapat memanfaatkan proses mediasi penal yang dilaksanakan oleh pihak penyidik kepolisian dengan mudah dan beranggapan bahwa terkait pencurian ringan hanya dapat di selesaikan dengan cara mudah, sehingga tidak menimbulkan efek jera dan potensi mengulangi perbuatannya. Bagi korban pun akan merasa bahwa tindakan pencurian ringan tersebut bukan suatu kejahatan yang perlu di antisipasi, mengingat proses penyelesaiannya yang mudah, korban akan merasa khawatir dapat terjadi kejadian yang sama yang akan menimpa dirinya maupun terhadap orang lain. Bagi masyarakat sekitar juga akan lebih merasa was - was atau khawatir dengan lingkungannya yang terdapat pelaku tindak kejahata,walaupun tindak kejahatan tersebut tindak pidana ringan, namun asumsi masyarakat akan menimbulkan keresahan.
\end{abstract}

\section{Kata Kunci : Penyelesaian ; Tindak Pidana Ringan; Rasa Keadilan}

\section{ABSTRACT}

Police Investigators in settling cases of minor crimes in this case are petty theft, usually by mediating the penalties because they are to achieve legal justice, legal certainty, and usefulness while still maintaining the principle of simple justice, so that the loss of the victim can be returned immediately, so that time efficiency which can be resolved faster, then in terms of the cost of handling cases is lighter or less compared to cases that are proceeded until the trial. However, this does not make the best solution for minor criminal offenses, in this case, petty theft, because the perpetrators can take advantage of the penal mediation process carried out by the police investigator easily and assume that minor theft related can only be resolved easily, so as not to cause the deterrent effect of potential repeating his actions. For the victims, they will feel that the act of petty theft is not a crime that needs to be anticipated, given the easy process of resolution, the victim will feel worried that the same thing will happen to him and to others. For the surrounding community, they will also feel more anxious or worried about the environment where there are perpetrators of crime, even though the crime is a minor crime, but the community's assumption will cause unrest.

\section{Keywords: settlement, light crime, sense of justice.}




\section{A. PENDAHULUAN}

Kepolisian Negara Republik Indonesia adalah bagian dari administrasi pemerintahan yang fungsinya untuk memelihara keteraturan serta ketertiban dalam masyarakat, menegakkan hukum, dan mendeteksi kejahatan serta mencegah terjadinya kejahatan. Polisi juga memiliki fungsi sebagai pengayom masyarakat dari ancaman dan tindak kejahatan yang mengganggu rasa aman serta merugikan secara kejiwaan dam material, dengan cara memelihara keteraturan dan ketertiban sosial, menegakkan hukum atau lebih tepatnya menegakkan keadilan dalam masyarakat berdasarkan hukum.. ${ }^{1}$ pidananya singkat dimana dapat diselesaikan dengan upaya mediasi, namun terdapat nilai sosial agar pelaku tindak kejahatan ringan menyadari kesalahannya dan tidak mengulanginya lagi. Dalam sistem penegakan hukum pidana di Indonesia, sebenarnya para penegak hukum telah diberikan wewenang tertentu oleh undangundang untuk mengesampingkan perkara pidana atau menyelesaikan perkara pidana tanpa meneruskannya ke pengadilan (sarana non penal). Seperti halnya kepolisian, sebagaimana diatur dalam Pasal 18 Undang-Undang No. 2 tahun 2002 tentang Polri, telah memberikan hak kepada polisi (penyidik) untuk melakukan diskresi (discretion), yakni hak untuk tidak memproses hukum terhadap tindak pidana sepanjang demi kepentingan umum maupun moral, karena diskresi pada hakikatnya berada diantara hukum dan moral. Dalam penjelasan Pasal 18 undang-undang ini memberikan pengertian mengenai "bertindak menurut penilaian sendiri" sebagai suatu tindakan yang dapat dilakukan oleh anggota Polri yang dalam bertindak harus mempertimbangkan manfaat dan resiko serta biaya dan keuntungan (cost and benefit) dari tindakannya yang benar-benar untuk kepentingan umum.

Dalam konteks kehadiran masyarakat yang mau untuk patuh pada hukum ataupun yang telah patuh hukum dalam suatu negara hukum, maka semangat yang muncul dewasa ini adalah semangat pengenyampingan perkara pidana untuk tidak mempergunakan proses penegakan hukum melalui proses litigasi atau melalui sarana penal. Adapun yang dapat dijadikan indikator terkait semangat dalam penyelesaian perkara pidana melalui sarana non penal atau non litigasi ini antara lain sebagai berikut :

1. Adanya keinginan masyarakat untuk menyelesaikan perkara pidana yang sifatnya ringan dan hanya menimbulkan kerugian kecil dengan menggunakan proses-proses perdamaian melalui jalur non penal atau non litigasi.

2. Dukungan masyarakat melalui account jejaring sosial seperti face book, twitter maupun di media massa (baik media cetak maupun elektronik) lainnya terhadap perkara pidana yang menimpa masyarakatkecil di wilayah Indonesia yang tentunyamenginginkan penyelesaian yang arif dan bijaksana dengan tidak membawa perkara pidana tersebut ke ranah hukum atau setidak-tidaknya diselesaikan melalui jalur non penal atau non litigasi dalam rangka mewujudkan keadilan substansial.

3. Keinginan aparat penegak hukum khususnya penyidik di kepolisian untuk menyelesaikan perkara-perkara pidana yang sifatnya ringan dan menimbulkan kerugian kecil termasuk menghentikan perkara pidanayang bukan delik aduan tetapioleh para pihakyang berperkara (pelapor) telah dicabut laporannya (laporan polisi), tentunya hal ini tidak terlepas dari kesepakatan korban dan pelaku tindak pidana tersebut dengan semangat kebersamaan dan dukungan masyarakat luas.

4. Kebijakanuntuktidaklekas-lekasmembawakasusyangkecil(perkarapidanaringan)dengan kerugian kecil ke jalur penyidikan oleh aparat penegak hukum khususnya di Kepolisian, tentunya selaras dengan model kegiatan kepolisian "perpolisian komunitas" (community policing) yang dalam konteks Polri dikembangkan dengan dua elemen minimal yakni kemitraan(partnership)danpemecahanmasalah(problem solving). Halitutercermin dalam 
Surat Keputusan Kapolri No.Pol: Skep/737/X/2005 tertanggal 13 oktober 2005 tentang Kebijakan dan Strategi Penerapan Model Perpolisian Masyarakat dalam Penyelenggaraan Tugas Polri. Dalam kebijakan ini hendak dipacu inisiatif maupun kemampuan masyarakat yang dibantu kepolisian setempat guna mengupayakan terjadinya pemecahan masalah terkait kasus-kasus lokal dan bersifat ringan. Pemberian kewenangan dan tanggung jawab kepada petugas Polmas dan Forum Kemitraan Polisi Masyarakat (FKPM) harus bersifat mandiri(otonom) dan independen dalammengambil langkah-langkah pemecahan masalah dan penyelesaian tindak pidana ringan/konflik antar warga maupun antara warga dengan polisi dan pejabat setempat.

5. Semangat ini pula tercermin dengan dikeluarkannya Surat Telegram Kapolri No. Pol. : B/3022/XII/2009/SDEOPS tanggal 14 Desember 2009 tentang Penanganan Kasus Melalui Alternatif Dispute Resolusion (ADR). Di sini dijelaskan bahwa salah satu bentuk penyelesaianmasalah dalam penerapan Polmasadalah penerapankonsepAlternatifDispute Resolution (ADR), yakni pola penyelesaian masalah sosial melalui jalur alternatif selain proses hukum atau non litigasi antara lain melalui upaya perdamaian.

Dari beberapa indikator di atas, pengenyampingan perkara pidana dilakukan guna mencapai suatu situasi "menang-menang" (win-win) antara pihak-pihak terkait, yang diperkirakan juga akan lebih menyembuhkan (healing) terkait para pihak yang terlibat (khususnya korban), serta lebih resolutif (sebagai suatu kata bentukan "resolusi" yang dapat diartikan sebagai "tercapainya kembali solusi yang sebelumnya tidak lagi diperoleh"). Minimal, pengakhiran konflik atau sengketa khususnya dalam perkara pidana bisa dilakukan tanpa ada pihak yang kehilangan muka (elegant solution). Di samping itu, perlunya konsepsi pemikiran yang merespons pengembangan sistem penegakan hukum pidana atau sistem peradilan pidana dengan menitikberatkan pada keterlibatan masyarakat dan korban serta pelaku dalam penyelesaian perkara pidana. Konsepsi ini berbasis pada penyelesaian perkara pidana secara musyawarah antara pelaku dan korban serta keterlibatan masyarakat maupun alternatif penyelesaian perkara di luar proses hukum atau non litigasi / non penal melalui upaya perdamaian seperti mediasi penal.

\section{B. METODE PENELITIAN}

Pendekatan penelitian adalah jabaran tentang teori apa yang di gunakan dalam pembahasan setiap rumusan masalah, dan dapat juga di maknai sebagai pendekatan yang digunakan dalam pengelolaan data dalam penelitian hukum non-doktrinal. Adapun pendekatan penelitian yang di gunakan dalam penelitian adalah normatif empiris, yang dalam pengertiannya adalah Metode penelitian hukum normatif empiris ini pada dasarnya merupakan penggabungan antara pendekatan hukum normatif dengan adanya penambahan berbagai unsur empiris. Metode penelitian normatif-empiris mengenai implementasi ketentuan hukum normatif .dalam aksinya pada setiap peristiwa hukum tertentu yang terjadi dalam suatu masyarakat.

\section{PEMBAHASAN}

\section{Sejarah, Latar Belakang dan Perkembangan Konsep Mediasi Penal Dikaitkan dengan Ide Restorative Justice}

Perkembangan ide mediasi penal tidak lepas dari perkembangan ide restorative justice sebagai salah satu ide pembaharuan hukum pidana (penal reform), karena konsep mediasi penal pada dasarnya merupakan salah satu sarana dalam mewujudkan pelaksanaan konsep restorative justice dalam penyelesaian perkara pidana. Mediasi penal sebagai mekanisme 
penyelesaian perkara pidana dalam mewujudkan keadilan restoratif (restorative justice). Mediasi penal dengan pendekatan restorative justice menjadi hal yang sangat penting dalam dewasa ini sebagai ide pembaharuan hukum pidana (penal reform).

\section{a. Mediasi Penal dalam Lintasan Sejarah}

Banyak penulis menganggap restorative justice dan mediasi penal bukanlah konsep yang baru. Keberadaannya barangkali sama tuanya dengan hukum pidana itu sendiri. Bahkan beribu-ribu tahun lalu, dalam upaya penanganan perkara pidana, pendekatan restorative justice melalui mekanisme mediasi penal justru ditempatkan sebagai mekanisme utama bagi penanganan tindak pidana. Menurut Eva Achjani Zulfa dalam tulisannya mengatakan bahwa di Negara-negara lain di dunia, ada beberapa contoh mengemuka dan banyak diungkapkan oleh para penulis tentang perkembangan hukum pidana, di mana menyebutkan bahwa restorative justice sebenarnya berasal dari aturan hukum purba yang mencantumkan hal terkait nilai-nilai restorative justice tersebut antara lain ${ }^{2}$ :

a. Kitab Ur-Nammi Sumeria (2060 S.M), mencantumkan ganti rugi sebagai satu jenis sanksi bagi semua tindak pidana;

b. Kitab Hammurabi (1700 S.M) mendekripsikan adanya ganti rugi sebagai satu jenis sanksi atas tindak pidana terhadap harta benda;

c. Hukum "Twelve Table" Romawi(496M), mengatur mengenai pembayaran dengan jumlah dua kali harga barang bagi pelaku perkara pencurian.

Selanjutnya dalam sejarah kerajaan-kerajaan yang pernah ada dan hidup di wilayah nusantara (Indonesia), di dalam aturan hukumnya juga mencantumkan hal-hal terkait nilai-nilai restorative justice baik melalui penyelesaian perkara pidana melalui sarana mediasi maupun lainnya, antara lain Kitab Kutara Manawa / Kitab Gajahmada (abad ke-14) yang dinyatakan sebagai kitab hukum pidana yang diterapkan masa pemerintahan Majapahit, Kitab Simbur Cahaya dinyatakan sebagai sistem peradatan yang diterapkan masa pemerintahan Kesultanan Palembang Darussalam (abad ke-16) dan Kitab Kuntara Raja Niti atau Cephalo 12 dan Cephalo 80 di Lampung (abad ke-16).

\section{b. Mediasi Penal dalam Hukum Adat Indonesia}

Penyelesaian sengketa dengan penggunaan sarana mediasi untuk mencapai perdamaian selain dikenal dalam hukum yang hidup dalam masyarakat yang bersumber dari nilai-nilai religious seperti dalam Hukum Islam, juga dikenal dalam hukum yang hidup dalam masyarakat yang bersumber dari nilai-nilai hukum adat. Tentunya antara nilai-nilai hukum adat dan nilainilai religius ini saling terkait dan saling melengkapi. Penyelesaian sengketa menurut Hukum Adat dapat dilakukan melalui musyawarah (mediasi). Dalam hal ini para pemuka masyarakat atau tokoh adat dapat menjalankan fungsi sebagai mediator. Misalnya penyelesaian sengketa yang sering dipraktikkan oleh masyarakat Aceh seperti: Di'iet, Sayam, Suloh dan Peumat Jaroe. ${ }^{3}$ Dalam tatanan masyarakat pedesaan di Sulawesi seringkali penyelesaian alternatif ini dipergunakan di luar pengadilan melalui mediasi (musyawarah perdamaian). Di Papua dikenal dengan istilah Upacara / Budaya Bakar Batu, sebagai simbol budaya lokal, yang digunakan untuk menyelesaikan sengketa atau perkara, termasuk perkara pidana, melalui upaya damai demi terpeliharanya harmoni sosial, sehingga proses pidana terhadap pelaku tindak pidana oleh aparatur negara dipandang tidak diperlukan lagi, karena justru dinilai akan merusak

2 Eva Achjani Zulfa (Dosen Hukum Pidana Fakultas Hukum UI Depok Indonesia), Restorative Justice di Indonesia (Peluang dan Tantangan Penerapannya), Restorative Centre, lihat http://evacentre.blogspot.com/p/restorative-justice-di-indonesia.html, diakses tanggal 4 November 2011

3 Ibid, hlm. 252 
kembali harmoni sosial yang sudah tercapai. Demikian juga dalam Kerapatan Adat Negeri di Minangkabau, ada suatu lembaga adat yang menyelesaikan perselisihan dengan "musyawarah" yang lebih umum dikenal dengan negosiasi. Begitu pula di Bali, melalui desa adat pakraman diterapkan adanya awig-awig yang merupakan dimensi lain identik dengan penyelesaian perkara di luar pengadilan melalui mediasi penal. ${ }^{4}$

\section{c. Perkembangan Ide Mediasi Penal Masa Kini ${ }^{5}$}

Seperti yang sudah dijelaskan sebelumnya bahwa mediasi penal merupakan salah satu bentuk alternatif penyelesaian sengketa di luar pengadilan (yang biasa dikenal dengan istilah ADR atau "Alternative Dispute Resolution"). Ide atau wacana dimasukkannya ADR dalam penyelesaian perkara pidana, antara lain terlihat dari perkembangan sebagai berikut :

a. Dalam dokumen penunjang Kongres PBB ke-9/1995 yang berkaitan dengan manajemen peradilan pidana (yaitu dokumen A/CONF.169/6) diungkapkan perlunya semua negara mempertimbangkan "privatizing some law enforcement and justice functions" dan “alternativedisputeresolution/ADR”(berupamediasi,konsiliasi,restitusi,dankompensasi) dalam sistem peradilan pidana.

b. DalamlaporanKongres PBBke-9/1995tentang "ThePreventionofCrimeand the Treatment of Offenders" (dokumen A/CONF. 169/16),

c. Dalam"InternationalPenal Reform Conference"yangdiselenggarakan di Royal Holloway College, University of London, pada tanggal 13-17 April 1999.

d. Pada 15 September 1999, Komisi Para Menteri Dewan Eropa (the Committee of Ministers of the Council of Europe) telah menerima Recommendation No. R(99) 19 tentang "Mediation in Penal Matters".

e. Dalam Deklarasi Wina, Kongres PBB ke-10/2000 (dokumen A/CONF. 187/4/Rev.3), antara lain dikemukakan bahwa untuk memberikan perlindungan kepadakorban kejahatan, hendaknya diintrodusir mekanisme mediasi dan peradilan restoratif (restorative justice).

f. Pada 15 Maret 2001, Uni Eropa membuat the EU Council Framework Decision tentang "kedudukankorbandidalamprosespidana"(theStandingofVictimsinCriminalProceedings) - EU (2001/220/JBZ) yang di dalamnya termasuk juga masalah mediasi.

g. Pada tanggal 24 Juli 2002, Ecosoc (PBB) telah menerima Resolusi 2002/12 mengenai "Basic Principles on the Use of Restorative Justice Programmes in Criminal Matters" yang di dalamnya juga mencakup masalah mediasi. ${ }^{6}$

Dengan demikian, sejak tahun 1995 melalui Kongres PBB ke-9 sampai dengan tahun 2002 (Resolusi 2002/12 yang telah diterima Ecosoc (PBB) tentang Basic Principles on the Use of Restoratife Justice Programmes in Criminal Matters), masalah mediasi dalam perkara pidana sudah masuk dalam agenda pembahasan di tingkat internasional. Tentunya, yang

4 Lilik Mulyadi (Wakil Ketua Pengadilan Negeri Jakarta Utara, Koordinator Peneliti dan Narasumber dalam penelitian tentang "Mediasi Penal dalam Sistem Peradilan Pidana di Indonesia", di wilayah Pengadilan Tinggi Palangkaraya, Mataram, Jambii dan Semarang pada bulan Juni-Juli 2011), Mediasi Penal dalam Sistem Peradilan Pidana Di Indonesia (Pengkajian Asas, Norma, dan Praktik), Makalah disampaikan dalam Seminar Hasil Penelitian tentang "Mediasi Penal dalam Sistem Peradilan Pidana di Indonesia", diselenggarakan oleh Pusat Penelitian dan Pengembangan Hukum dan Peradilan, Badan Penelitian dan Pengembangan dan Pendidikan dan Pelatihan Hukum dan Peradilan Mahkamah Agung RI (Badan Litbang Diklat Kumdil MARI), di Hotel Alila Pecenongan, Jakarta Pusat, pada tanggal 26 Oktober 2011, lihat http://pn-kepanjen. go.id/index.php?option=com_content\&task=view\&id=156 (bag 1), akses tanggal 23 Oktober 2011

5 Uraian ini didasarkan pada karya Barda Nawawi Arief, Mediasi Penal : Penyelesaian Perkara Pidana di Luar Pengadilan, (Semarang : Pustaka Magister, 2008), hlm 10-16, atau dapat pula dilihat dalam http://bardanawawi.files.wordpress.com/2009/12/mediasi-penal-edit-30-10-20081.doc.

6 Barda Nawawi Arief, ibid, hlm 16, mengutip Annemieke, ibid. Barda Nawawi Arief menerangkan sebagaimana yang tercantum dalam dokumen E/2002/INF/2/Add.2, international-research-project-report2 (sbr.: internet) 
melatarbelakangi pemikiran tersebut adalah adanya ide-ide pembaharuan hukum pidana (penal reform), antara lain ide perlindungan korban, ide harmonisasi, ide restorative justice, ide mengatasi kekakuan / formalitas dalam sistem yang berlaku, ide menghindari efek negatif dari sistem peradilan pidana dan sistem pemidanaan yang ada saat ini, khususnya dalam mencari alternatif lain dari pidana penjara, dsb.

\section{Keuntungan dan Kerugian penggunaan mediasi penal oleh anggota Polri untuk peny- elesaian tindak pidana ringan}

Fungsi kepolisian adalah salah satu fungsi pemerintahan negara di bidang pemeliharaan keamanan dan ketertiban masyarakat, penegakan hukum, perlindungan, pengayoman, dan pelayanan kepada masyarakat

Konsep keadilan restoratif merupakan kritik terhadap konsep sistem peradilan pidana yang melihat kejahatan sebagai pelanggaran terhadap aturan negara. Negara memiliki hak untuk menghukum para pelanggar agar tercipta stablitas sosial. Penderitaan korban dianggap selesai/ impas apabila negara telah membuat pelaku menderita. Akan tetapi hal tersebut merupakan konsep warisan kolonial yang dianggap tidak memberikan dampak yang positif untuk menekan angka kejahatan dan angka residivisme ${ }^{7}$.

Jadi keuntungan dan Kerugian pelaksanaan mediasi penal oleh anggota polri untuk penyelesaian tindak pidana ringan sebagai berikut :

\section{Keuntungan}

a. Tercapainyarasakeadilanolehpelakudankorban, dengancarapelakudengankesadarannya mengakui kesalahan dan meminta maaf pada korban, dan bersedia untuk bertanggung jawab atas kerugian yang di alami oleh korban.

b. Terdapat kepastian proses hukum yang di lakukan penyidik Polri dalam menyelesaikan tindak pidana ringan dengan cara mediasi penal. Sehingga korban, pelaku, dan masyarakat mendapatkan kepastian hukum atas penyelesaian tindak pidana ringan.

c. Efisiensi waktu yang lebih cepat.

d. Biaya yang di butuhkan sedikit, di bandingkan ketika masih berlanjut ke ranah pengadilan.

e. Melibatkan masyarakat, korban ,dan pelaku, serta penyelidik/penyidik sebagai mediator untuk pemenuhan rasa keadilan kepada semua pihak dan untuk tercapainya penjaminan HAM.

Kerugian

a. Tidak adanya pembatasan pelaksanaan mediasi penal untuk pelaku yang mengulangi perbuatan tindak pidananya, sehingga terjadi keresahan di lingkungan masyarakat yang diakibatkan oleh pelaku yang mengulangi melakukan perbuatan tindak pidana ringan karena tidak jera dengan penanganan menggunakan mediasi penal.

b. PeraturanhukumyangmengaturmediasipenaldilingkunganPolriuntukpenanganantindak pidana ringan belum sepenuhnya dapat menjamin hak asasi pelaku, korban dan masyarakat terbukti masih adanya pelaku tindak pidana ringan yang mengulangi perbuatannya dan di tangani atau diselesaikan dengan mediasi penal secara berulang yang berakibat timbulnya keresahan dan tidak tertibnya lingkungan masyarakat yang menjadikan tidak terjaminnya HAM masyarakat.

\section{Kelemahan Peraturan Hukum yang dijadikan dasar Hukum anggota Polri dalam melakukan mediasi penal untuk tindak pidana ringan.}

Beragamnya tindak pidana berupa kejahatan maupun pelanggaran yang terjadi di Indonesia, berdampak pada pelaksanaan tugas pokok dan fungsi kepolisian khususnya yang

7

Afthonul Afif, 2015, Pemaafan, Rekonsiliasi dan Restoraive Justice, Pustaka Pelajar, Yogyakarta, hlm. 341-350 
berkaitan dengan kewenangan polisi sebagai penyidik dalam proses di bidang pidana sesuai dengan yang diatur dalam Peraturan Kepala Kepolisian Negara Republik Indonesia Nomor 6 Tahun 2019 Tentang Penyidikan tindak Pidana ${ }^{8}$. Dalam melaksanakan tugasnya di bidang proses pidana, kepolisian memiliki kewenangan untuk mengambil tindakan lain menurut pertimbangan dan hati nuraninya yang tidak bertentangan dengan aturan hukum yang di sebut dengan diskresi kepolisian. Dengan adanya diskresi kepolisian ini polisi dapat mengambil keputusan dan bertindak menurut penilaiannya sendiri yang tidak bertentangan dengan aturan hukum, sesuai yang di atur dalam pasal 18 Undang - Undang Nomor 2 Tahun 2002. Seperti perkara-perkara yang tegolong tindak pidana ringan contohnya perkara pencurian ringan. Dikategorikan sebagai pencurian ringan dimana nominal/harga barangnya tidak lebih $\mathrm{Rp}$. 250, 00 (dua ratus lima puluh rupiah). Pencurian ringan yang diatur dalam pasal 364 KUHP (dalam Hananta, 2017: 20) adalah kualifikasi yang diberikan oleh Undang-Undang (KUHP) terhadap tindak pidana pencurian dengan batas kerugian tertentu yang dinilai ringan. Drmikia menurut Pasal 1 Peraturan Mahkamah Agung Nomor 02 Tahun 2012 tentang Penyesuaian Batasan Tindak Pidana Ringan dan Jumlah Denda KUHP ("PERMA 02/2012") kemudian menguraikan bahwa: Kata-kata "dua ratus puluh lima rupiah" dalam pasal 364, 373, 379, 384, 407 dan pasal 482 KUHP dibaca menjadi Rp 2.500.000,00 (dua juta lima ratus ribu rupiah). Dalam kasus pencurian ringan, maka pelaku tidak ditahan dan perkara dilaksanakan melalui acara pemeriksaan cepat sebagaimana dimaksud dalam Bagian Menimbang huruf b PERMA 02/2012, yang berbunyi: bahwa apabila nilai uang yang ada dalam KUHP tersebut disesuaikan dengan kondisi saat ini, maka penanganan perkara tindak pidana ringan seperti pencurian ringan, penipuan ringan, penggelapan ringan dan sejenisnya dapat ditangani secara proporsional mengingat ancaman hukuman paling tinggi yang dapat dijatuhkan hanyalah tiga bulan penjara, dan terhadap tersangka atau terdakwatidak dapat dikenakan penahanan, serta acara pemeriksaan yang digunakan adalah Acara Pemeriksaan Cepat. Selain itu perkara-perkara tersebut tidak dapat diajukan upaya hukum Kasasi.

Resrorative Justice menjadi solusi terbaik, proses dimana mereka yang terlibat perilaku tindak pidana atau kriminal baik itu korban, pelaku, keluarga yangt terlibat atau masyarakat luas, semua di perlukan untuk berpeluang dalam menyelesaikan masalah yang terjadi, Sebagai langkah bijaksana guna menyelesaikan masalah hukum dan saling berhubungan. Penyelesaian menggunakan Keadilan restoratif (Resrorative Justice) ini dapat dilakukan apabila pencurian tersebut dapat dikategorikan sebagai pencurian ringan. Penerapan mediasi oleh aparat kepolisian khususnya penyidik merupakan upaya dalam menerapkan atau mewujudkan Restorative Justice. Upaya aparat kepolisian ini dimaksudkan untuk kemaslahatan orang atau masyarakat banyak dimana penerapan hukum tidak selalu harus berupa sanksi dan hukuman pidana, tetapi dapat menciptakan keadilan bagi korban dan menyadarkan pelakuakan kesalahannya untuk menjadi masyarakat yang lebih baik lagi. Menerapkan mediasi sebagai upaya penerapan Restorative Justice, pihak kepolisian dituntut untuk dapat menyeleksi atau memilih perkara mana yang yang pantas untuk dilanjutkan ke tahap pengadilan atau tidak. Namun dalam pelaksanaannya masih banyak kendala yang harus di hadapi oleh penyidik Kepolisian.

Penyidik Kepolisian dalam pelaksanaannya, menggunakan peraturan hukum Surat Edaran Kepolisian Negara Republik Indonesia Nomor: SE/8/VII/2018 Tentang Penerapan Keadilan Restoratif (restorative jutice) dalam Penyelesaian Perkara Pidana. Surat Edaran inilah yang menjadi landasan hukum bagi penyidik polri yang menangani perkara tindak pidana ringan. kelebihan di gunakannya penyelesaian tindak pidana ringan dengan mediasi penal tersebut telah di jelaskan dalam surat edaran kapolri 2018 yakni mewujudkan tujuan hukum yaitu 
keadilan,kepastian hukum dan kemanfaatan dengan tetap mengedepankan asas peradilan yang sederhana, cepat, dan biaya ringan ${ }^{9}$. Namun di balik kelebihannya terdapat juga kelemahannya. Selama ini peraturan hukum yang di pakai penyidik polri Terkait pedoman penanganannya dijelaskan sebagai berikut: diberitahukan/ di permaklumkan untuk penyelesaian perkara dengan pendekatan Restorative Jutice agar tidak memunculkan keberagaman administrasi penyelidikan/penyidikan dan perbedaan imterpretasi para penyidik serta penyimpangan dalam pelaksanaanya, diperlukan pedoman penanganan sebagai berikut : Terpenuhinya syarat materiil yaitu : 1. Tidak menimbulkan keresahan masyarakat dan tidak ada penolakan masyarakat, 2. tidak berdampak konflik sosial, 3 . Adanya pernyataan semua pihak yang terlibat untuk tidak keberatan, dan melepaskan hak menuntutnya di hadapan hukum, 4. Prinsip pembatas : a. Pada pelaku : 1. Tingkat kesalahan pelaku tidak berat, yakni kesalahan (schuld atau mensrea) dalam bentuk kesengajaan (dolus atau opzet) terutama kesengajaan sebagai maksud atau tujuan (opzet als oogmerk) 2. Pelaku bukan residivis ${ }^{10}$.

\section{Formulasi Peraturan Hukum yang mengatur mediasi penal di lingkungan Polri untuk penanganan tindak pidana yang dapat menjamin hak asasi pelaku, korban dan masyara- kat.}

Kepolisian Negara Republik Indonesia atau yang sering disingkat dengan Polri dalam kaitannya dengan Pemerintahan adalah salah satu fungsi pemerintahan negara di bidang pemeliharaan keamanan dan ketertiban masyarakat, penegakan hukum, perlindungan, pengayoman, dan pelayanan kepada masyarakat, yang bertujuan untuk mewujudkan keamanan dalam negeri yang meliputi terpeliharanya keamanan dan ketertiban masyarakat, tertib dan tegaknya hukum, terselenggranya perlindungan, pengayoman, dan pelayanan kepada masyarakat, serta terbinanya ketentraman masyarakat dengan menjunjung tinggi hak asasi manusia. Kepolisian dalam menindak lanjuti proses pidana di atur dalam pasal 16 ayat (2) Undang - Undang kepolisian di sebutkan terkaittindakan penyelidikan dan penyidikan yang dilaksanakan jika memenuhi syarat sebagai berikut : a.tidak bertentangan dengan suatu aturan hukum; b.selaras dengan kewajiban hukum yang mengharuskan tindakan tersebut dilakukan; c.harus patut, masuk akal, dan termasuk dalam lingkungan jabatannya; d.pertimbangan yang layak berdasarkan keadaan yang memaksa; dan e.menghormati hak asasi manusia. Berkaitan dengan wewenang kepolisian di sebutkan pada pasal 16 Dalam melaksanakan tugas dan wewenangnya, pejabat Kepolisian Negara Republik Indonesia senantiasa bertindak berdasarkan norma hukum dan mengindahkan norma agama, kesopanan, kesusilaan, serta menjunjung tinggi hak asasi manusia. (2) Dalam melaksanakan tugas dan wewenang sebagaimana dimaksud dalam ayat (1), Kepolisian Negara Republik Indonesia mengutamakan tindakan pencegahan. Jadi jelas dalam peraturan hukum lingkungan Polri dalam pelaksanaan terkait tugas dan wewenangnya masih mengedapankan hak asasi manusia.

Sistem peradilan pidana bersifat offender oriented, yaitu terlalu mengedepankan hakhak tersangka atau terdakwa sebagaimana dikemukakan oleh Andi Hamzah:“ Dalam membahas hukum acara pidana khususnya yang berkaitan dengan hak-hak asasi manusia, ada kecenderungan untuk mengupas hal-hal yang berkaitan dengan hak-hak tersangka tanpa memerhatikan pula hak-hak para korban. Korban tidak diberikan kewenangan dan tidak terlibat secara aktif dalam proses penyidikan dan persidangan sehingga ia kehilangan kesempatan untuk memperjuangkan hak-hak dan memulihkan keadaannya akibat suatu kejahatan"11

9 Lihat di Surat Edaran Kepolisian Negara Republik Indonesia Nomor : SE/8/VII/2018 Tentang Penerapan Keadilan Restoratif (restorative jutice) dalam Penyelesaian Perkara Pidana nomor 2 point "a"

10 Ibid, Nomor 3 point "a"

11 Dikdik M. Arief Mansur \& Elisatri Gultom, 2008, Urgensi Perlindungan Korban Kejahatan Antara Norma Dan Realita, Raja Graf- 
Penjaminan Hak asasi manusia, dalam hal ini pelaku, korban, dan pihak masyarakat di jelaksan dalam Undang-Undang Republik Indonesianomor 39 Tahun 1999 Tentang Hak Asasi Manusia. Hak masyarakat Yaitu Bagian Kesatu Hak untuk Hidup di jelaskan pada pasal 9 bahwa :

(1) Setiap orang berhak untuk hidup, mempertahankan hidup dan meningkatkan taraf kehidupannya.

(2) Setiap orang berhak tenteram, aman, damai, bahagia, sejahtera lahir dan batin.

(3) Setiap orang berhak atas lingkungan hidup yang baik dan sehat.

Untuk korban dan tersangka Hak memperoleh keadilan di jelaskan pada pasal 17 yaitu : Setiap orang, tanpa diskriminasi, berhak untuk memperoleh keadilan dengan mengajukan permohonan, pengaduan, dan gugatan, baik dalam perkara pidana, perdata, maupun administrasi serta diadili melalui proses peradilan yang bebas dan tidak memihak, sesuai dengan hukum acara yang menjamin pemeriksaan yang obyektif oleh hakim yang jujur dan adil untuk memperoleh putusan yang adil dan benar.

Pasal 18 dijelaskan hak untuk tersangka bahwa :

(1) Setiap orang yang ditangkap, ditahan, dan dituntut karena disangka melakukan sesuatu tindak pidana berhak dianggap tidak bersalah, sampai dibuktikan kesalahannya secara sah dalam suatu sidang pengadilan dan diberikan segala jaminan hukum yang diperlukan untuk pembelaannya, sesuai dengan ketentuan perundang-undangan.

(2) Setiap orang tidak boleh dituntut untuk dihukum atau dijatuhi pidana, kecuali berdasarkan suatu peraturan perundang-undangan yang sudah ada sebelum tindak pidana ini dilakukannya.

(3) Setiap ada perubahan dalam perturan perundang-undangan, maka berlaku ketentuan yang paling menguntungkan bagi tersangka.

(4) Setiap orang yang diperiksa berhak mendapatkan bantuan hukum sejak saat penyidikan sampai adanya putusan pengadilan yang telah memperoleh kekuatan hukum tetap.

(5) Setiap orang tidak dapat dituntut untuk kedua kalinya dalam perkara yang sama atas suatu perbuatan yang telah memperoleh putusan pengadilan yang berkekuatan hukum tetap.

Mediasi penal di lingkungan Polri untuk penanganan tindak pidana ringan belum sepenuhnya dapat menjamin hak asasi pelaku, korban dan masyarakat terbukti masih adanya pelaku tindak pidana ringan yang mengulangi perbuatannya dan di tangani atau diselesaikan dengan mediasi penal secara berulang yang berakibat timbulnya keresahan dan tidak tertibnya lingkungan masyarakat yang menjadikan tidak terjaminnya HAM masyarakat.

\section{D.KESIMPULAN}

Bahwa penggunaan mediasi penal oleh anggota Polri untuk penyelesaian tindak pidana ringan memiliki keuntungan berupa : pertama, Tercapainya rasa keadilan oleh pelaku dan korban, dengan cara pelaku dengan kesadarannya mengakui kesalahan dan meminta maaf pada korban, dan bersedia untuk bertanggung jawab atas kerugian yang di alami oleh korban.Kedua. Terdapat kepastian proses hukum yang di lakukan penyidik Polri dalam menyelesaikan tindak pidana ringan dengan cara mediasi penal. Sehingga korban, pelaku, dan masyarakat mendapatkan kepastian hukum atas penyelesaian tindak pidana ringan. Ketiga, Efisiensi waktu yang lebih cepat. Keempat, Biaya yang di butuhkan sedikit, di bandingkan ketika masih berlanjut ke ranah pengadilan. Kelima, Melibatkan masyarakat, korban ,dan pelaku, serta penyelidik/penyidik sebagai mediator untuk pemenuhan rasa keadilan kepada semua pihak dan untuk tercapainya penjaminan HAM. Kerugiannya berupa : pertama, Tidak 
adanya pembatasan pelaksanaan mediasi penal untuk pelaku yang mengulangi perbuatan tindak pidananya, sehingga terjadi keresahan di lingkungan masyarakat yang diakibatkan oleh pelaku yang mengulangi melakukan perbuatan tindak pidana ringan karena tidak jera dengan penanganan menggunakan mediasi penal. Kedua, Peraturan hukum yang mengatur mediasi penal di lingkungan Polri untuk penanganan tindak pidana ringan belum sepenuhnya dapat menjamin hak asasi pelaku, korban dan masyarakat terbukti masih adanya pelaku tindak pidana ringan yang mengulangi perbuatannya dan di tangani atau diselesaikan dengan mediasi penal secara berulang yang berakibat timbulnya keresahan dan tidak tertibnya lingkungan masyarakat yang menjadikan tidak terjaminnya HAM masyarakat. Bahwa adanya kelemahan peraturan hukum yang menjadi dasar hukum anggota Polri dalam melakukan mediasi penal dalam tindak pidana ringan yaitu tidak adanya pembatasan pelaksanaan mediasi penal untuk pelaku yang mengulangi perbuatan tindak pidananya, sehingga terjadi keresahan di lingkungan masyarakat yang diakibatkan oleh pelaku yang mengulangi melakukan perbuatan tindak pidana ringan karena tidak jera dengan penanganan menggunakan mediasi penal Bahwa peraturan hukum yang mengatur mediasi penal di lingkungan Polri untuk penanganan tindak pidana ringan belum sepenuhnya dapat menjamin hak asasi pelaku, korban dan masyarakat terbukti masih adanya pelaku tindak pidana ringan yang mengulangi perbuatannya dan di tangani atau diselesaikan dengan mediasi penal secara berulang yang berakibat timbulnya keresahan dan tidak tertibnya lingkungan masyarakat yang menjadikan tidak terjaminnya HAM masyarakat Perlunya merumuskan peraturan hukum yang mengatur mediasi penal di lingkungan Polri untuk penanganan tindak pidana ringan untuk penjaminan hak asasi pelaku, korban, dan masyarakat. Merevisi atau menyempurnakan Perkap Nomor 6 tahun 2019 dan/atau Surat Edaran Kapolri Nomor 8 tahun 2018 dengan menambahkan pembatasan pelaksanaan mediasi penal/ keadailan restoratif.

\section{DAFTAR PUSTAKA}

Atok,A., Al Rosyid ,2015, Konsep Pembentukan Peraturan-Perundang-undangan;Teori, Sejarah dan Perbandingan dengan Beberapa Negara Bikameral, Setara Press, Malang.

Afthonul Afif, 2015, Pemaafan Rekonsiliasi dan Restoraive Justice, Pustaka Pelajar, Yogyakarta.

Dikdik M. Arief Mansur \& Elisatri Gultom, 2008, Urgensi Perlindungan Korban Kejahatan Antara Norma Dan Realita, Raja Grafindo, Jakarta.

Gijssels dan Mark van Hoecke, 2001, What is Rechtsteorie, 1982, diterjemahkan oleh B.Arief Sidharta, Apakah Teori Hukum Itu,: FH UNPAR, Bandung.

Harahap, Yahya, 2009, Pembahasan Permasalahan Dan Penerapan KUHP, Sinar Grafika. Jakarta.

Ilyas, Amir, 2012, Asas-Asas Hukum Pidana, Rangkang Education Yogyakarta \& PuKAPIndonesia, Yogyakarta.

Kusumohamidjojo, Budiono, 2006, Teori Hukum, dilema antara Hukum dan Kekuasaan,: 
Yrama Widya, Bandung.

Lexy J. Moleong (II), 2004, Metodologi Penelitian Kualitatif, Remaja Rosdakarya Bandung.

Marlina, 2012, Peradilan Pidana Anak di Indonesia Pengembangan Konsep Diversi dan Restorative Justice, PT refika Aditama,Bandung.

\section{Webbsite Internet :}

http://anjarnawanyep.wordpress.com/konsep-diversi-dan restorativejustice

New York State Dispute Resolution Association, Inc., Alternative Dispute Resolution in New York State, An Overview, sbr internet. Di Akses Pada tanggal 18 Mei 2020. Pukul $20.00 \mathrm{wib}$

Detlev Frehsee (Professor of Criminology and Criminal Law, University of Bielefeld, Germany), "Restitution and Offender-Victim Arrangement in German Criminal Law: Development and Theoretical Implications", http://wings.buffalo.edu/law/ bclc/bclr. htm. Diakses pada tanggal 18 Mei 2020 pukul 22.00Wib.

Stefanie Tränkle, The Tension between Judicial Control and Autonomy in Victim-Offender Media-tion - a Microsociological Study of a Paradoxical Procedure Based on Examples of the Mediation Process in Germany and France, http://www. iuscrim. mpg.de/forsch/krim/traenkle_e.html. Diakses pada tanggal 20 mei 2020 pukul 17.00 wib. 